\title{
The importance of vowel diacritics for the temporary retention of high and low frequency Hebrew words of varying syllabic length
}

\author{
Vered Vaknin-Nusbaum • Paul Miller
}

Published online: 17 November 2010

(C) The Psychonomic Society 2010

\begin{abstract}
This study investigates the importance of vowel diacritics for the retention of Hebrew word lists, with word lists being manipulated along the dimension of word frequency and syllabic length. Eighty university students participated in the study. Half of the participants (40) were tested with the word lists presented in fully-pointed (voweled) Hebrew while the other half (40) were given the word lists in unpointed Hebrew (with vowel diacritics removed). Analyses of each group's recall rates and recallorder accuracy indicate that, overall, the presence of vowel diacritics had no facilitating effect on the participants' quantitative and qualitative Short Term Memory (STM) performance. This was found to be true whether word frequency (high vs. medium to low) or syllabic length (mono vs. trisyllabic) were computed as within-subject factors. Attempts to adequately interpret the absence of a pointing effect on STM performance based upon Orthographic Depth Hypothesis (ODH) and Grain Size Theory (GST) proved unfruitful. The authors propose an adaptation of the GST to the peculiarities of Hebrew orthography and discuss a morphology-centered grain-size theory (MGST).
\end{abstract}

Keywords Reading $\cdot$ Hebrew $\cdot$ STM $\cdot$ Pointing ·

Vowel diacritics

V. Vaknin-Nusbaum $(\bowtie)$

Department of Education, Western Galilee College,

Akko, Israel

e-mail: vered.vaknin@gmail.com

V. Vaknin-Nusbaum $\cdot$ P. Miller

Department of Education, University of Haifa,

Haifa, Israel

\section{Introduction}

Widely-held current reading theories (e.g., Frost, 1998; Jackson \& Coltheart, 2001; Share, 1995) maintain the existence of an intrinsic link between reading acquisition and the internalization of the alphabetic principle. The core of this principle is a cognitive procedure that associates specific letter graphemes with specific phonemes (the elementary units of spoken language). Once the alphabetic principle has been internalized and automatized, a readerat least in orthographies with regular grapheme-to-phoneme correspondence - should be able to reliably generate phonological forms for all written words. The meaning of such phonological forms - similar to the meaning of words perceived by the ear-is assumed to be mediated via the reader's phonological lexicon (spoken vocabulary) (Bentin, 1997; Frost, 1998; Liberman, 1989).

Alphabetic writing systems typically use limited sets of letter graphemes (letters or letter combinations) for the representation of phonemes, whether the referenced phoneme is a consonant, a vowel, or some other phonetic entity used for the generation of words in the read language. There are languages, however, that are exceptional in this regard because they depict some of the phonetic information of words by means of small diacritical marks rather than by letter graphemes, a method known as pointing (see Miller, 2002; Shimron, 1993, 1999, 2006). A typical example of such a writing system is 'pointed Hebrew', the orthography investigated in this paper. In pointed Hebrew the representation of a word's consonantal information is realized by means of letter graphemes. Vowels, however, are primarily depicted by diacritical marks indicated below or above the consonantal letter string. For example, the Hebrew word 
for 'dog' is Appendix 1) ${ }^{1}$. This CVCVC string is written as a string of three consonant letters, with pointing representing the evowel added below the first and the second letter. ${ }^{2}$

Letter graphemes, in conjunction with pointing, turn Hebrew into a highly shallow orthography in which the correct pronunciation of written words is possible in a straightforward manner based upon the application of a grapheme-to-phoneme conversion procedure-the alphabetic principle often referred to as the non-lexical (phonological) reading route (Jackson \& Coltheart, 2001). Therefore, in the Hebrew shallow orthography, it would be logical to assume that pointing is basically beneficial to the reading process. Indeed, in the Jewish population of Israel, for which Hebrew is the official language, children learn to read in fully pointed Hebrew, an orthography that depicts both a word's consonantal and vowel information in a reliable manner. Interestingly, however, beginning with the second grade, pointing, which indicates written words' vowels, is gradually omitted from school materials. Furthermore, above grade level three, Jewish Israeli children read texts that are almost exclusively presented in unpointed Hebrew ${ }^{3}$ (Shimron, 1993). As a consequence to the omission of vowel diacritics, Hebrew shifts from a shallow orthography into a deep orthography. Therefore, for the efficient recognition of written words, Hebrew readers may have to rely upon a more direct reading route that retrieves the phonological information of written words via well-specified orthographic representations associated with specific entries in the phonological lexicon. These entries are assumed to reflect Hebrew morphemes, such as an abstract word root and a word pattern, that together provide the meaning of the word (Frost, 2006). ${ }^{4}$

The two reading routes mentioned above have been conceptualized in the form of an Orthographic Depth Hypothesis (ODH) (e.g. Frost, Katz, \& Bentin, 1987). According to this hypothesis, readers tend to adjust their reliance on the two possible reading routes to the particular

\footnotetext{
${ }^{1}$ Hebrew is read from the right to the left.

${ }^{2}$ In addition to pointing, Hebrew also uses some letter graphemes called 'mothers of reading' for the designation of vowel information (for example the letters ' $'$ ' [Aleph], 'ה' [He]), 'M' [Vav], "' [Yod]). Unlike vowel diacritics, which are spatially dissociated, mothers of reading (like vowel graphemes in English) are integrated into the consonantal letter string (for a more complete description of Hebrew, see Shimron, 1993).

${ }^{3}$ Although above grade level three, the Hebrew reader reads (and produces) almost exclusively unpointed text, some documents like biblical text, poetry, etc., are always printed in pointed style to guarantee precise pronunciation.

${ }^{4}$ Roots and word patterns are abstract morphological that in combination form Hebrew words with specific meanings. For example, the Hebrew word MISPARA ("hairdressing salon") is a derivation of the word root 'S-P-R' which is infixed into the phonological pattern 'MI-A-A'.
}

requirements of the read orthography. In shallow orthographies (e.g., pointed Hebrew, Serbo-Croatian, Turkish), in which converting graphemes into phonemes is relatively direct and unambiguous, the recognition of written words is hypothesized to proceed primarily along a non-lexical phonological route. In inconsistent orthographies (e.g., English) or phonologically underspecified orthographies (e.g., unpointed Hebrew), however, such a phonological route may prove less effective as a pathway to written word meaning. As a consequence, readers may be compelled to rely to a greater extent on a lexical route that mediates word recognition via detailed orthographic knowledge.

According to $\mathrm{ODH}$, the processing of written words along a lexical route requires the reader to have wellinternalized and sufficiently specified orthographic representations. Such representations are assumed to exist for high-frequency words, but to a lesser degree for lowfrequency words. Following this line of reasoning, it would be logical to assume that the initial recognition of lowfrequency words in Hebrew would benefit more from the presence of vowel diacritics, which would eventually be transformed into faster and more accurate word recognition and enhanced short-term memory performance. The role of diacritics to the domain of short-term memory (STM) is examined in the study presented here.

In reviewing the literature, there are numerous studies that have focused on the functional status of pointing, and currently existing evidence reflects a plurality of approaches that attempt to clarify this important issue. Several of these endeavors have focused on the contribution of pointing to the processing of written Hebrew words at the lexical (word) level using naming, along with a lexical decision paradigm, as a method of investigation. Findings obtained from such studies suggest that both competent adult Hebrew readers (Frost, 1994, 1995; Koriat, 1984, 1985a, 1985b; Navon \& Shimron, 1981; Smolka \& Eviatar, 2006) and children at various school levels (Miller, 2002; Share \& Levin, 1999; Shimron, 1997, 1999) prove sensitive to the presence (or absence) of vowel diacritics. For example, pointing was found to lead to a quantitative and qualitative enhancement in the naming of isolated words (Frost, 1994; Koriat, 1984; Navon \& Shimron, 1981; Smolka \& Eviatar, 2006).

Of particular interest in this regard is a naming study that manipulated the amount of non-depicted vowel information at the graphemic level due to the omission of pointing (Frost, 1995). Findings obtained from this study validate that naming latencies for unpointed Hebrew words of the same syllabic length increase proportionally with the amount of non-indicated vowels. Such evidence actually suggests that, at least in relation to voiced reading, the presence of vowel diacritics (pointing) facilitate the processing of written words. As has been shown by another 
line of reading studies, the occurrence of such pointingrelated enhancement in the voiced reading of Hebrew was not restricted to the processing of isolated words but was equally evident in the voiced reading of connected text (Eshel, 1985; Morhayim, 1988; Share \& Levin, 1999).

Given that Hebrew script, when presented in pointed style, is transparent orthographically and thus, unambiguous with regard to grapheme-phoneme correspondence, the finding that vowel diacritics facilitates the voiced reading of written Hebrew appears sound. However, in the course of making sense of written materials, Hebrew readers most likely will not be asked to voice what they read. In such instances, vowel diacritics probably cease to enhance the processing of written Hebrew. Findings from studies using experimental paradigms that did not require the overt voicing of the presented word stimuli (lexical and categorical decision paradigms) suggest that this indeed may be the case. In fact, the majority of evidence revealed by such studies corroborates the assumption that, under unvoiced conditions, the presence or absence of pointing does not significantly alter the quantitative (speed) and qualitative (accuracy) lexical or categorical processing of visually presented word stimuli (Frost, 1995; Koriat, 1985a; Miller, 2002, 2004; Navon \& Shimron, 1985). Moreover, pointing was found to enhance the processing of isolated words only with regard to specific word categories, such as lowfrequency words (Frost, 1994; see also Koriat, 1985b).

The assumption that pointing-beyond facilitating the vocalization of written Hebrew-does not significantly boost the reading process is further supported by studies designed to assess its impact on the comprehension of connected text. Evidence obtained from such endeavors (Even, 1995; Nachmani-Ronen, 2000; Shimron, 1999; Shimron \& Sivan, 1994) indeed substantiates that the omission of pointing, per se, does not exert a detrimental impact on reading comprehension (see also Almady, 2007 for similar findings in Arabic). This seems to be true even though the removal of vowel diacritics from Hebrew words results in a significant decrease in the amount of phonological information represented at the graphemic level that readers are hypothesized to use as a gateway to the meaning of written words.

In sum, for Hebrew readers with average and aboveaverage reading skills, the contribution of vowel diacritics to the processing of written materials seems to be marginal (Even, 1995; Miller, 2002; Nachmani-Ronen, 2000; Shimron, 1999; Shimron \& Sivan, 1994) and may be limited to instances where such individuals are asked to read aloud (Eshel, 1985; Morhayim, 1988), or asked to process lowfrequency words (Frost, 1994; Koriat, 1985b). Moreover, there are few studies that consider the impact of pointing on the temporary retention of written words. Our study was designed to expand questions regarding the role of diacritics to the domain of short-term memory (STM). Specifically, it represents an attempt to clarify whether the omission of vowel diacritics interferes with the temporary verbatim retention of written words and to determine whether such bias is modified by word frequency/familiarity and syllabic length.

The proper elaboration of the meaning of connected text (word phrase, sentence, etc.) is intrinsically linked to the reader's ability to temporally retain the read words as well as the order in which they are encountered. This is particularly true in instances where text conveys information that does not map on the reader's immediate world knowledge, hence being unfamiliar information. In such instances, the reader cannot elucidate the meaning of the read material based upon its mere top-down processing but he/she has to elaborate proper comprehension by integrating the meaning of single words based upon rule-based knowledge ${ }^{5}$ reflected in word order. Given this to be true, an understanding of how the presence (or absence) of vowel diacritics impacts the temporary retention of consecutively presented written words is a prerequisite for a complete understanding of the reading process as a whole. Unfortunately, attempts to address this important issue have so far been scarce and findings obtained are inconclusive. In one of these studies, Shimron (1999) examined in two different experiments whether the presence of vowel diacritics facilitates the temporary retention of written Hebrew words by 3 rd and 6th grade students. In the first experiment, participants were asked to recognize two lists of 20 consecutively presented words from two test word lists, each comprising half of the target words with the remainder being words not previously seen. One of the lists was presented with vowel diacritics and the other without. Findings obtained from the performance analysis suggested that adding vowel diacritics had no beneficial impact on the retention of written words per se, although it seemed to speed up the process of retrieval by recognition in the mixed condition. Similar findings were found in a second experiment were participants were asked to write down the words they could remember, rather than recognize them from within a test list as required in the first experiment. Again, analyses of their recall performance failed to corroborate that pointing per se enhanced the temporary retention of words in a straightforward manner. Shimron (1999) concluded that "overall the contribution of vowelization [pointing] to short-term and episodic memory was far from massive" (p. 311) and may actually be limited to the stage of word decoding.

\footnotetext{
5 The term 'rule-based, linguistic knowledge' refers to knowledge concerning the morphological, syntactic, and grammatical structure of the reader's spoken language.
} 
In the above reported experiments (Shimron, 1999), the number of items presented to the participants was 20 , hence far beyond the capacity of STM ( $7 \pm 2$ items [Baddeley, 1978; Miller, 1956]). Therefore, the recognition/recall of at least some of the presented words may have been mediated by long-term memory rather than by STM. Moreover, in both experiments the contribution of vowel diacritics to the temporary retention of written words was derived from the analysis of performance on a single word list per vowel condition (e.g., one pointed list vs. one unpointed list). Given such limitations, conclusions drawn from Shimron's (1999) study should be read with some caution.

A more recent study examined the impact of pointing on the written ordered short-term recall of 12 lists of eight consecutive visually presented Hebrew words, half presented with vowel diacritics and the other half without (Miller, 2002). Participants included one group of regularly developing hearing students and two groups of poor readers in which one group was comprised of orally raised deaf students and the second of deaf children of deaf parents for whom sign language was the mother tongue. Evidence revealed from the analysis of immediate recall in this study suggests that, overall, pointing facilitates the retention of written words, including the retention of their presentation order. However, fine-tuned analyses suggest that such facilitation was restricted to individuals who, in the course of formal education, were encouraged to rely upon a phonological reading strategy (orally raised deaf students) and for whom-due to insufficient reading experiencemany written words may still lack orthographic representations that sustain their processing. For the other reader groups, in contrast, the effect of pointing seems to be rather marginal.

In summarizing evidence presented in the above mentioned STM studies (Miller, 2002; Shimron, 1999) one cannot dismiss the impression that - contrary to predictions made by a strong ODH - the contribution of vowel diacritics to the temporary memorization of written words and, consequently, to the comprehension of connected text is minor, if at all. However, considering research (Frost, 1994; see also Koriat, 1985b) that investigates the role of pointing in the lexical processing of low frequency words, some caution seems to be warranted as to the extent of this conclusion. Indeed, it may well be that the observed processing enhancement caused by pointing in relation to this word category eventually is transferred to the STM. Given that for the reader every written word is at first a low frequency word (a word that is orthographically unfamiliar; Share, 2008), understanding how pointing contributes to the retention of this word category is essential for determining the final value of vowel diacritics for reading in Hebrew.

\section{Research questions and hypotheses}

The primary impetus of this study was to provide answers to the following research question: Is the contribution of pointing to the temporary retention of written words biased by word frequency? In order to answer this question, two groups of university students were asked for immediate recall of 12 seriatim presented word lists each comprised of eight written Hebrew words. In six of the lists the words were of relatively low frequency whereas the word frequency of the items included in the remaining six lists was significantly higher. For one of the participant groups the stimulus lists were presented with vowel diacritics (Pgroup) whereas for the other participant group the stimulus lists were presented unpointed (UP-group).

Two research hypotheses were tested in relation to the above research question and with reference to an ODH. The first anticipated that the immediate recall of the stimulus lists by the P-group would be quantitatively and qualitatively better than the recall of the UP-group given that pointed Hebrew sustains direct and unambiguous graphemes to phonemes translation. The second hypothesis predicted that the performance discrepancy between the participant groups would be markedly more prominent for lists comprised of low-frequency words in comparison to lists built from words of higher frequency. As mentioned earlier, according to ODH, low-frequency or unfamiliar words may not be recognizable along the lexical reading route because they lack or have no sufficiently consolidated orthographic representations. In other words, the recognition of such words is expected to be gained by the vowel information provided by pointing.

Vowels are intrinsic components of syllables. Given that pointing indicates vowels in Hebrew written words, its presence may be particularly beneficial for the retention of multisyllabic (long) words (see word-length effect in Baddeley, Thomson, \& Buchanan, 1975). Given this to be the case, syllabic length in conjunction with word frequency may bear particular potential in disclosing the impact of pointing on the temporary retention of written words. To provide a satisfactory answer for this possibility, the stimulus lists used for assessing the interaction between pointing and word frequency were manipulated along a syllabic length dimension, with half of the target lists in each frequency category comprising monosyllabic words and the other half trisyllabic words.

With reference to the above double-manipulation, three additional research hypotheses were tested. The first predicted that recalling monosyllabic words would be easier and more accurate than recalling trisyllabic words for both the $\mathrm{P}$ and UP groups. The second hypothesis forecast that the omission of vowel diacritics would prove more detrimental for target lists composed of trisyllabic words than for target lists built of monosyllabic words. Finally, it was hypothesized that the 
impact of pointing on recall performance would interact with both word frequency and syllabic length, with the omission of pointing being particularly harmful to the temporary retention of trisyllabic low-frequency word lists.

\section{Method}

Participants

Participants were 80 university students recruited via a flyer distributed on campus offering paid participation. For all of the participants, Hebrew was the first spoken and written (read) language. Age-range of the participants was 2030 years, with the majority being in the early 20 s. All of the participants had normal or corrected-to-normal vision. Only university students attesting that they had no history of hearing impairment or learning disability were included in the participant sample.

Participants were randomly assigned to either the P-group or the UP group. The P-group consisted of 11 males and 29 females who saw the stimulus materials in fully pointed Hebrew. In the UP-group, consisting of 12 males and 28 females, the stimulus materials were presented unpointed.

\section{Stimuli and design}

Ninety-six Hebrew words representing different word categories (nouns, verbs, adjectives, etc.) were used for the preparation of 12 equal stimulus lists (eight words in each list), which were presented in consecutive order on a computer display to the participants of each group. An additional pool of 24 words (three word lists) was prepared to be used for warm-up and explanation.

All lists were prepared in two versions, a pointed version and an unpointed version. Half of the lists (6) were comprised of words rated as low-frequency words (LFlists) whereas the other half was built from items rated to be of notably higher frequency (HF-lists). Among the lists prepared for each frequency category, half (3) were built of monosyllabic words (MS) and the other half (3) of trisyllabic words (TS). The words assigned to each list were semantically unrelated (see Appendix 2).

In order to control for possible semantic bias on the effects of word frequency and syllabic length, the words used to build LF-lists were synonyms of the words used in the HF-lists (see Appendix 2). As a result, both the LF and the HF lists automatically preserved the same grammatical function. For example, the noun "baby" would be used in the HF-list whereas the noun "toddler" in the LF-list.

The words in each list were seen by a participant only once with the same presentation order being used for all participants. They were presented in sequence, with a between stimuli interval of half a second and a stimuli presentation span of two seconds. Stimuli presentation time was chosen to be long enough to permit fast verbal rehearsal of all eight word stimuli.

To compensate for a possible practice or fatigue effect, the 12 stimulus lists were treated as four separate blocks, each comprising three stimulus lists: (1) low-frequency/ monosyllabic lists (LF-MS); low-frequency/trisyllabic lists (LF-TS); (2) high-frequency/monosyllabic lists (HF-MS); and (3) high-frequency/trisyllabic lists (HF-TS). Two rotations were applied to the presentation of the different stimulus lists. The first rotation rotated the four stimulus blocks whereas the second rotation rotated the three lists within each stimulus block.

\section{Word frequency estimates}

As mentioned earlier, the experiment material contained two sets of stimulus lists: half comprised words that were assumed to be low-frequency and the other half comprised synonyms of the same words that were assumed to be of significant higher frequency. In order to scientifically corroborate this ad hoc frequency estimate, 91 university students not participating in the study were asked to rate 96 (12 lists $x 8$ words) stimulus words presented by means of a questionnaire on a frequency/familiarity dimension on a scale from 1 (low) to 7 (high). The average rating of the words in the low-frequency list was $3.39(\mathrm{SD}=0.97)$ whereas the average rating was $5.43(\mathrm{SD}=0.89)$ for the words in the high frequency lists, with each word included in the low frequency/familiarity lists being markedly less frequent and familiar than its counterpart included in the high frequency/familiarity lists. In order to scientifically validate this frequency classification, we executed a paired ttest that compared the average frequency estimate of the two frequency categories. As presumed, the rating of the assumed high-frequency lists proved markedly higher in comparison to ratings of the assumed low-frequency lists, $t(90)=20.91, p<$ 0.001 . To further validate this frequency discrepancy, we retrieved the stimulus words' frequency from the Hebrew Word Frequency database of Ram Frost and David Plaut (http://translate.google.co.il/translate?hl=iw\&langpair=en $\%$ 7Ciw\&u=http://micro5.mscc.huji.ac.il/ frost/). Calculating average word frequency ratings for the assumed low and high frequency stimulus lists based upon these ratings confirmed that the words included in low frequency lists were indeed of much lower frequency in comparison to their high frequency counterparts (see Appendix 2).

Procedure

Each participant was examined individually in the investigators' Reading Research Lab that is located at the 
University of Haifa. A computer monitor (12", black/ green) was used for stimuli presentation. Stimuli presentation was computer-controlled. The consecutively presented word stimuli in either pointed or unpointed style were presented in 24" black Times New Roman font and appeared within a white frame located in the center of the computer display. During the between-stimuli presentation interval the space within the frame was blanked and set to black. To indicate the end of a sequence, the symbol of a small bright star was displayed following the disappearance of the last item of a series.

Prior to the test, participants were told that they would see several lists of words presented seriatim within a frame in the center of the monitor with a small star indicating the end of a series. Following the appearance of this star, subjects were instructed to write the words they could remember in the same order they appeared on a blank sheet in a notebook placed in front of them. In case they couldn't remember the order, they were instructed to write down the words in any order they like. Participants were told to write down all the words unpointed.

After task explanation, all participants received three practice trials. Testing was started only after their recall behavior indicated proper understanding of the task requirements. None of the participants demonstrated difficulties in understanding the task requirements. During experimentation, the presentation of the different stimulus lists was participant-paced. Recall for each stimulus list was written on a separate blank sheet. The time to write down the words from a list was not limited.

\section{Results}

The aim of this study was to learn about the contribution of pointing to the temporary retention of written words by skilled Hebrew readers. The experimental paradigm used to investigate this issue required the immediate, ordered recall of Hebrew words presented either pointed or unpointed. The analyses presented herewith refer to the performance of the participants in the STM experiment under different stimulus presentation conditions (pointed vs. unpointed).

Two aspects concerning the groups' recall behavior were examined in order to learn about the impact of pointing on the temporary retention of Hebrew words: (1) amount of recall, and (2) retention of item-presentation-order. The first of these aspects represents a quantitative dimension, whereas the second was more qualitative in nature.

Amount of recall

We conducted a repeated measures MANOVA to clarify the impact of word frequency and syllabic length on amount of immediate ordered recall. The participant groups' average recall for mono and trisyllabic high and low frequency word lists is presented in Table 1.

A statistical model computing word frequency (LF, HF) and syllabic length (MS, TS) as the within-subject factors and group (P-group, UP-group) as a between subject factor was used. The main effect of word frequency was statistically significant, $F(1,78)=33.94, p<0.001, \eta^{2}=0.30$. The main effect of syllabic length was also statistically significant, $F(1,78)=39.14, p<0.001, \eta^{2}=0.33$. The main effect of group (P-group, UP-group) was statistically insignificant. All the interactions between the three main effects were statistically insignificant (syllabic length $\mathrm{X}$ group $F(1,78)=$ $0.24, p=0.63$; frequency $\mathrm{X}$ group $F(1,78)=0.05, p=0.83$; syllabic length $\mathrm{X}$ frequency $F(1,78)=0.30, p=0.58$, respectively). The triple interaction between syllabic length $\mathrm{X}$ frequency $\mathrm{X}$ group failed to reach statistical significance as well, $F(1,78)=0.17, p=0.20)$.

\section{Order of recall}

We conducted a repeated measures MANOVA in order to clarify the impact of word frequency and syllabic length on the groups' retention of word presentation order. Accuracy of recall order reflects the degree to which recall order is congruent with stimulus presentation order. This variable was calculated as a percentile factor relative to the total number of words recalled from a word list. Average percentages of recall order accuracy for the two groups, overall, and with reference to word frequency and syllabic length are presented in Table 2.

A statistical model computing word frequency (LF, HF) and syllabic length (MS, TS) as the within-subject factors and group (pointed, unpointed) as a between subject factor was used. The main effect of word frequency was statistically insignificant, $F(1,78)=0.39, p=0.54$. The same was true for the syllabic length main effect, $F(1,78)=0.18, p=0.67$, and the group main effect, $F(1,78)=0.03, p=0.86$. All the interactions between the three main effects were statistically

Table 1 Average amount of recall for the two groups (standard deviations in parentheses) ${ }^{\mathrm{a}}$

\begin{tabular}{|c|c|c|c|c|}
\hline \multirow[t]{3}{*}{ Group } & \multicolumn{4}{|c|}{ Syllabic length } \\
\hline & \multicolumn{2}{|c|}{ Monosyllabic } & \multicolumn{2}{|l|}{ Trisyllabic } \\
\hline & HF-Lists & LF-Lists & HF-Lists & LF-Lists \\
\hline P-group & $5.96(1.12)$ & $5.65(1.06)$ & $5.63(1.23)$ & $5.06(1.15)$ \\
\hline UP-group & $6.05(1.06)$ & $5.53(0.93)$ & $5.61(0.84)$ & $5.19(1.01)$ \\
\hline All & $6.00(1.09)$ & $5.59(0.99)$ & $5.62(1.03)$ & $5.12(1.08)$ \\
\hline
\end{tabular}

$H F$ high frequency, $L F$ low frequency, $P$ pointed, $U P$ unpointed

${ }^{a}$ Average recall per test list out of eight words 
Table 2 Mean percentages recall order accuracy for the two participant groups (standard deviations in parentheses) ${ }^{\mathrm{a}}$

$H F$ high frequency, $L F$ low frequency

${ }^{a}$ Accuracy range $0-100$

\begin{tabular}{lllllll}
\hline Participant groups & \multicolumn{2}{l}{ Low frequency } & \multicolumn{2}{l}{ High frequency } & \multirow{2}{*}{ Overall } \\
\cline { 2 - 3 } & MS-Lists & TS-Lists & & MS-Lists & TS-Lists & \\
\hline Pointed & $88.03(17.71)$ & $88.04(18.15)$ & & $88.43(15.22)$ & $89.57(16.99)$ & $88.52(15.02)$ \\
Unpointed & $91.61(9.59)$ & $86.74(20.78)$ & $88.49(12.08)$ & $89.42(13.63)$ & $89.07(12.56)$ \\
All & $89.82(14.26)$ & $87.39(19.56)$ & & $88.46(13.65)$ & $89.49(15.30)$ & $88.80(13.76)$ \\
\hline
\end{tabular}

insignificant (syllabic length $\mathrm{X}$ group $F(1,78)=0.47, p=$ 0.50 ; frequency $\mathrm{X}$ group $F(1,78)=1.30, p=0.26$; syllabic length $\mathrm{X}$ frequency $F(1,78)=2.68, p=0.11)$. The triple interaction between syllabic length $\mathrm{X}$ frequency $\mathrm{X}$ group failed to reach statistical significance as well, $F(1,78)=$ $1.21, p=0.27)$.

\section{Discussion}

The primary impetus of this study was to provide answers to several questions relating to the contribution of pointing to reading, in general, and the temporary ordered retention of written words, in particular. The basic assumption underlying these questions was that pointing exerts a facilitating effect on the initial encoding of written words in Hebrew and, consequently, enhances their temporary retention in Working Memory (WM) (Kahn-Horowitz, 1995; Miller, 2002; Shimron, 1999). Contrary to this expectation, the recall performance of the two participant groups failed to corroborate this assumption. In fact, analyses of the different assessed recall dimensions (amount of recall, recall order accuracy) failed to reveal significant evidence for an enhancing pointing effect. This finding implies that adding vowel diacritics to Hebrew words may not facilitate their temporary retention.

Findings from this study suggest that the impact of pointing on the processing of written Hebrew words as the basis for their retention in WM is minor, if at all. This is in line with other studies that investigated the effect of pointing on the lexical and categorical processing of written isolated Hebrew words (Frost, 1995; Koriat, 1985a; Miller, 2002, 2004; Navon \& Shimron, 1985). However, as mentioned earlier, evidence obtained from some of these studies suggests that pointing may enhance the processing of specific word categories, such as low-frequency words (Frost, 1994; see also Koriat, 1985b).

The above possibility was also addressed in our study by hypothesizing that the performance discrepancy between the P-group and the UP-group would be markedly more prominent in the recall of LF-lists than in the recall of HFlists. Evidence obtained from our study failed to substantiate this prediction, as well. This finding is of particular interest given that the same analysis revealed a marked word frequency main effect, indicating that the number of recalled words from HF-lists was notably higher than that from LF-lists (see Table 1). The finding of nonsignificant interactions between the group effects and the word frequency effects in relation to both assessed recall dimensions suggests that the word frequency effect was not biased by pointing.

As mentioned earlier, syllabic length in conjunction with word frequency may bear particular potential in disclosing the impact of pointing on the temporary retention of written words. We tested three specific hypotheses to step-wise validate this assumption. The first predicted that recalling monosyllabic words would be easier and more accurate than recalling trisyllabic words. Findings revealed from the analyses of the P and UP-groups' performance on the different recall dimensions supported this syllabic-length hypothesis only with regard to the amount of recalled items. However, there was no evidence that syllabic length interfered with order of recall.

The second hypothesis, which also addresses syllabic length, claimed that the absence of vowel diacritics could prove to be particularly detrimental for target lists composed of trisyllabic words as opposed to target lists consisting of monosyllabic words. In other words, participants seeing unpointed word lists would have a greater disadvantage in recalling trisyllabic word lists than monosyllabic word lists. This is because the omission of vowel diacritics from trisyllabic words leads to greater underspecification of the phonology of Hebrew words at the grapheme level, a dearth that is expected to impede their phonological decoding more than when pointing is removed from monosyllabic words. Findings from the MANOVA analyses examining the interactions between the group effect and the syllabic length effect for the two assessed recall dimensions failed to support that pointing biased recall from MS-lists and TS-lists selectively. This seems to indicate that phonology may not have played a central role in the initial encoding of the target words.

Finally, it was hypothesized that the impact of pointing on recalled performance will interact with both word frequency and syllabic length, with the omission of pointing being particularly harmful to the temporary retention of trisyllabic low-frequency word lists. Contrary to expectations, there was no evidence for a significant tripleinteraction (word frequency $\mathrm{x}$ syllabic length $\mathrm{x}$ group) in relation to the two assessed recall dimensions. The finding that 
pointing did not enhance recall performance for low frequency words, in general, and for trisyllabic low frequency words, in particular, strongly suggests that vowel diacritics do not play a crucial role in the temporary retention of written words by adult skilled readers. Some findings suggest that this may be true not only for adult Hebrew readers but also for normally developing skilled readers at the elementary school level (Miller, 2004).

The evidence obtained from this study suggests that vowel diacritics do not have an impact on the temporary retention of Hebrew words even for trisyllabic low frequency word lists. This finding is incompatible with predictions made by an Orthographic Depth Hypothesis (ODH) according to which Hebrew readers should recognize unpointed low frequency words, in general, and unpointed multi-syllabic words, in particular, with reduced efficiency (e.g. Frost, Katz, \& Bentin, 1987). As a consequence of phonological underspecification in unpointed Hebrew, their processing along a phonological route should therefore prove less effective as a pathway to written word meaning.

Recently, a number of researchers have proposed an alternative explanation to the ODH in the form of a GrainSize Theory (GST) (Frost, 2006; Ziegler \& Goswami, 2005, 2006). This new approach deals with a variation in orthographic depth without the need to postulate a lexical reading route. We hoped this new approach would also be useful in explaining the absence of a pointing effect in our study.

According to GST, the (sub) lexical graphemic units converted into phonological units vary according to the orthographic depth of the read language. In shallow orthographies, these units are assumed to be small (single graphemes that are converted into phonemes), whereas in deep orthographies larger sublexical units (rimes, syllables, morphemes, etc.) may become the subject of this conversion process (Davis, 2005). The clear advantage of GST over a dual route reading model is that - by adjusting the size of the computed phonological units - it is able to deal in a flexible manner with variation in orthographic depth as a single route model, without the need of postulating the existence of a second orthographic knowledge-based lexical route.

In accordance with the GST (Frost, 2006; Ziegler \& Goswami, 2005, 2006), participants in this study who saw pointed target words should have shown better recall from STM than participants receiving the same target words unpointed, particularly for multi-syllabic and less frequent words. This is because in pointed Hebrew-a highly regular orthography - the grain size units processed phonologically are single letter graphemes and vowel diacritics. According to a GST, word recognition in pointed Hebrew, therefore, requires the application of a limited set of grapheme-tophoneme conversion rules (simple alphabetic principle). On the other hand, the efficient unambiguous recognition of unpointed Hebrew words should prove far less straightforward because it involves the identification and phonological processing of orthographic units of larger grain size. Such enhanced demands are expected to slowdown the word recognition process, a compromise that may well have a negative effect on the temporary retention of unpointed words in STM.

Findings from our study suggest that-similar to predictions made in accordance with the ODH (Frost et al., 1987) - participants' STM performance did not comply with predictions based on a GST in regard to the potential contribution of pointing to short-term recall via an enhancement of target word recognition. In other words, participants who saw pointed target words were not at an advantage due to the fact that vowel diacritics allowed them to process the phonological properties of the target words based upon consistent small grain-size units requiring merely the application of a simple alphabetic principal. It therefore seems that neither ODH nor GST in their original form provide a sufficient theoretical model that can explain why in our study, as well as in many other studies, Hebrew readers did not benefit from the presence of vowel didactics.

Taking a closer look at the special characteristic of the reading context encountered by the Hebrew reader may offer an additional potential explanation for the failure to find a pointing effect in our study as well as in others (see also Koriat, 1984; Navon \& Shimron, 1985). As stated earlier, above the third grade Hebrew readers read almost exclusively unpointed text. As a result, a simple graphemeto-phoneme conversion procedure that computes small grain-size units (letter graphemes and vowel diacritics) for word recognition ceases to be reliable. Instead, the Hebrew reader is compelled to develop a reading strategy that pays attention to larger, probably morpho-graphemic grain-size units (Frost, 2006), such as a word's abstract root morpheme or a specific inflectional or derivational morpheme pattern (for a detailed discussion on the role of morphology in reading Hebrew see Frost, 2009).

It should be noted that once pointing is removed from text, the Hebrew reader will rarely apply a straightforward grapheme-to-phoneme conversion procedure in which small grain-size units reliably sustain the recognition of words. Therefore, in order to guarantee the efficient processing of unpointed Hebrew, the reader is forced to read via a strategy that constantly gives attention to larger grain-size units. It seems reasonable to assume that in the course of an extensive reading experience such units not only become internalized as permanent representations but their application for the recognition of written words is set as a default strategy that is applied to unpointed and pointed text all together. This would reasonably explain why adding pointing to the target words in our study had no notable 
positive impact upon their temporary retention. Apparently, this was simply redundant information that the participants did not use as they encoded the target words in STM. It also would explain why the notable word frequency and syllabic length effects were not found to interact with pointing.

The fact that both ODH and GST apparently do not account for the missing pointing effect in our study may be due to the way orthographic depth manifests itself in unpointed Hebrew. Although both English and Hebrew are considered deep (opaque) orthographies, the origin of their opaqueness has essentially different roots. In the former, the reason for this opaqueness is inconsistency in grapheme-tophoneme translation. In contrast, what makes Hebrew a deep orthography is an underspecification of a word's phonological properties at the grapheme level due to the omission of the vowel diacritics and not due to graphemeto-phoneme inconsistency. Despite the omission, the graphemic information presented in unpointed Hebrew words remains rather invariant, reflecting morphological clusters as large grain-size units (Frost, 2006, 2009). It can be assumed that retreating to a small grain-size strategy in reading Hebrew is likely to be restricted to instances where the application of such large grain-size units is insufficient, as in the case of new words for which the reader may not have yet internalized specific large grain-size units.

In summary, findings from this STM study suggest that skilled Hebrew readers tend to process pointed and unpointed Hebrew words by means of one and the same reading strategy. It is further suggested that the (sub) lexical orthographic units referenced for this purpose are likely to be larger than single letter graphemes. This seems to be true even in instances in which, due to the presence of vowel diacritics, written Hebrew words could be effectively recognized via a simple grapheme-to-phoneme conversion procedure. It should, however, be emphasized that the same may not hold true for novice and unskilled readers. Therefore, to determine the contribution of pointing to the temporary retention of written words, including its development with increased reading experience, future research should expand the application of the research paradigm used in our study to readers from different school levels, as well as to reader groups with various diagnosed reading disorders.

Findings from our study have been considered from the perspective of a dual route ODH and a single route GST. Findings do not seem to support a hypothesis that grain size units in Hebrew are optimally adjusted to the depth of the read orthography. Rather, the Hebrew readers transfer the large grain-size strategy they seem to use for accessing the meaning of unpointed Hebrew words to the reading of pointed words. Consequently, they do not benefit from the phonological information vowel diacritics contribute, as suggested by ODH and GST.
We used a between-subject design for examining the contribution of pointing to the temporary retention of written words. The finding of strikingly similar word frequency and syllabic length effects in relation to both participant groups principally confirms the adequacy of this design for studying the impact of word processing peculiarities on STM performance. However, administering the same research paradigm in future research as a withinsubject design or even as a mixed between/within-subject design may present unique potential for strengthening conclusions drawn from this study.

Finally, the conclusions drawn from this study are based upon a limited set of words and, therefore, warrant some caution in making a generalization about reading in Hebrew as a whole. Moreover, the assumption made by a morphemecentered grain-size theory (MGST) should be tested with research paradigms that manipulate grain-size units in Hebrew words in a straightforward manner. Comparing the contribution of pointing to the processing of inconsistent Hebrew words may bear great potential in understanding the use of a large grain-size units strategy in reading Hebrew.

\section{Appendix 1}

The Hebrew Alphabet

\begin{tabular}{|c|c|c|}
\hline Hebrew Print & Orthographic Transcription & Phonetic Transcription \\
\hline$\kappa$ & & ' \\
\hline ב & $b$ & $b, v$ \\
\hline$\lambda$ & g & $\mathrm{g}$ \\
\hline $\mathbf{T}$ & $d$ & $d$ \\
\hline ה & $\mathrm{h}$ & $\mathrm{h}$ \\
\hline 1 & $w$ & $0, u, v$ \\
\hline$T$ & $\mathrm{z}$ & $\mathrm{z}$ \\
\hline$n$ & $x$ & $x$ \\
\hline 0 & $\mathrm{t}$ & $\mathrm{t}$ \\
\hline ' & $y$ & $\mathrm{I}, \mathrm{y}$ \\
\hline כ & K & $K, x$ \\
\hline 7 & $k$ & $\mathrm{x}$ \\
\hline ל & 1 & 1 \\
\hline$n$ & $\mathrm{~m}$ & $\mathrm{~m}$ \\
\hline 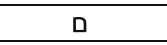 & $\mathrm{M}$ & $\mathrm{m}$ \\
\hline 了 & $\mathrm{n}$ & $\mathrm{n}$ \\
\hline 1 & $\mathrm{~N}$ & $\mathrm{n}$ \\
\hline 0 & $s$ & $s$ \\
\hline ע & 5 & $S$ \\
\hline פ & $\mathrm{p}$ & $\mathrm{p}, \mathrm{f}$ \\
\hline 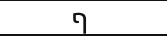 & $\mathrm{p}$ & $\mathrm{f}$ \\
\hline$y$ & $\underline{\mathrm{S}}$ & $\check{S}, \mathrm{c}$ \\
\hline$Y$ & $\breve{S}$ & $\check{\mathrm{S}}, \mathrm{c}$ \\
\hline P & $q$ & $\mathrm{k}$ \\
\hline 7 & $\mathrm{r}$ & $\mathrm{r}, \mathrm{v}$ \\
\hline ש & $\mathrm{S}$ & $\mathrm{S}$ \\
\hline ת & $\mathrm{t}$ & $\mathrm{t}$ \\
\hline
\end{tabular}




\section{Appendix 2}

\begin{tabular}{|c|c|c|c|c|c|c|c|c|c|c|c|}
\hline \multicolumn{6}{|c|}{ Low frequency } & \multicolumn{6}{|c|}{ High Frequency } \\
\hline \multicolumn{3}{|c|}{ Monosyllabic } & \multicolumn{3}{|c|}{ Trisyllabic } & \multicolumn{3}{|c|}{ Monosyllabic } & \multicolumn{3}{|c|}{$\underline{\text { Trisyllabic }}$} \\
\hline 1 & 2 & 3 & 4 & 5 & 6 & 7 & 8 & 9 & 10 & 11 & 12 \\
\hline $\begin{array}{l}\text { rs } \\
\text { run } \\
\text { 'ac }\end{array}$ & $\begin{array}{l}\text { rp } \\
\text { end } \\
k e c\end{array}$ & $\begin{array}{c}\text { ה } \\
\text { echo } \\
\text { hed }\end{array}$ & $\begin{array}{c}\text { כרכרכי } \\
\text { carriage } \\
\text { kirkara }\end{array}$ & $\begin{array}{c}\text { שלה } \\
\text { flame } \\
\text { Šalhevet }\end{array}$ & $\begin{array}{c}\text { הפוג } \\
\text { rest } \\
\text { hafuga }\end{array}$ & $\begin{array}{l}\text { ro } \\
\text { run } \\
\text { rac }\end{array}$ & $\begin{array}{l}\text { סוף } \\
\text { end } \\
\text { sof }\end{array}$ & $\begin{array}{c}\text { קול } \\
\text { voice } \\
\text { kol }\end{array}$ & $\begin{array}{c}\text { עג } \\
\text { carriage } \\
\text { agala }\end{array}$ & $\begin{array}{l}\text { להבל } \\
\text { flame } \\
\text { lehava }\end{array}$ & $\begin{array}{l}\text { break } \\
\text { breaka }\end{array}$ \\
\hline $\begin{array}{c}\text { לת } \\
\text { barrow } \\
\text { tel }\end{array}$ & $\begin{array}{c}\text { א } \\
\text { only } \\
a x\end{array}$ & $\begin{array}{c}\text { עu } \\
\text { move } \\
\text { nas }\end{array}$ & $\begin{array}{c}\text { תחבולה } \\
\text { trick } \\
\text { taxbula }\end{array}$ & $\begin{array}{c}\text { התגלות } \\
\text { revelation } \\
\text { hitgalut }\end{array}$ & $\begin{array}{c}\text { הגיח } \\
\text { to burst } \\
\text { out } \\
\text { higi'ax }\end{array}$ & $\begin{array}{c}\text { הר } \\
\text { mountain } \\
\text { har }\end{array}$ & $\begin{array}{l}\text { pר } \\
\text { just } \\
\text { rak }\end{array}$ & $\begin{array}{c}i \\
\text { move } \\
z i v\end{array}$ & $\begin{array}{c}\text { מזימה } \\
\text { conspiracy } \\
\text { mezima }\end{array}$ & $\begin{array}{c}\text { הופעה } \\
\text { appearance } \\
\text { hofa'a }\end{array}$ & $\begin{array}{c}\text { התפרץ } \\
\text { to break } \\
\text { out } \\
\text { hitparec }\end{array}$ \\
\hline $\begin{array}{l}\text { צו } \\
\text { nectar } \\
\text { cuf }\end{array}$ & $\begin{array}{c}\text { רד } \\
\text { to live } \\
\text { dar }\end{array}$ & $\begin{array}{c}\text { זי } \\
\text { brightness } \\
z i v\end{array}$ & $\begin{array}{c}\text { עששית } \\
\text { oil lamp } \\
\text { a ̌́šSit }\end{array}$ & $\begin{array}{l}\text { oפ } \\
\text { ship } \\
\text { sfina }\end{array}$ & $\begin{array}{c}\text { האפיל } \\
\text { to darken } \\
\text { he'efil }\end{array}$ & $\begin{array}{l}\text { מיק } \\
\text { juice } \\
\text { mic }\end{array}$ & $\begin{array}{l}\text { רג } \\
\text { to } \\
\text { live } \\
\text { gar }\end{array}$ & $\begin{array}{l}\text { אוght } \\
\text { ligh } \\
\text { or }\end{array}$ & $\begin{array}{c}\text { מנורה } \\
\text { lamp } \\
\text { menora }\end{array}$ & $\begin{array}{l}\text { אניה } \\
\text { ship } \\
\text { oniya }\end{array}$ & $\begin{array}{c}\text { החשיד } \\
\text { to darken } \\
\text { hex } \check{S} i x\end{array}$ \\
\hline $\begin{array}{c}\text { טיט } \\
\text { mortar } \\
\text { tit }\end{array}$ & $\begin{array}{c}\text { זיק } \\
\text { spark } \\
z i k\end{array}$ & $\begin{array}{l}\text { og } \\
\text { stripe } \\
\text { pas }\end{array}$ & $\begin{array}{c}\text { הפרזה } \\
\text { announcement } \\
\text { haxraza }\end{array}$ & $\begin{array}{c}\text { cישועי } \\
\text { salvation } \\
\text { yeŠsu'a }\end{array}$ & $\begin{array}{c}\text { מעידה } \\
\text { stumble } \\
\text { me'ida }\end{array}$ & $\begin{array}{c}\text { pla } \\
\text { mud } \\
\text { boc }\end{array}$ & $\begin{array}{l}\text { אure } \\
\text { fire } \\
e \check{S}\end{array}$ & $\begin{array}{l}\text { קine } \\
\text { line } \\
\text { kav }\end{array}$ & $\begin{array}{c}\text { הודעה } \\
\text { message } \\
\text { hoda'a }\end{array}$ & $\begin{array}{c}\text { הצוn } \\
\text { saving } \\
\text { hacala }\end{array}$ & $\begin{array}{c}\text { fילוl } \\
\text { fall } \\
\text { nefila }\end{array}$ \\
\hline $\begin{array}{l}\text { pit } \\
\text { bor }\end{array}$ & $\begin{array}{c}\text { שר } \\
\text { low- } \\
\text { poor- } \\
\text { ra } \breve{S}\end{array}$ & $\underset{z i z}{\operatorname{ir}}$ & $\begin{array}{l}\text { אריח } \\
\text { tile } \\
\text { ari'ax }\end{array}$ & $\begin{array}{c}\text { מפלה } \\
\text { defeat } \\
\text { mapala }\end{array}$ & $\begin{array}{l}\text { לבנה } \\
\text { moon } \\
\text { levana }\end{array}$ & $\begin{array}{c}\text { חור } \\
\text { hole } \\
\text { xor }\end{array}$ & $\begin{array}{c}\text { לד } \\
\text { low- } \\
\text { poor- } \\
\text { dal }\end{array}$ & $\begin{array}{c}\text { ש' } \\
\text { tooth } \\
\text { Šen }\end{array}$ & $\begin{array}{c}\text { בל } \\
\text { tile } \\
\text { balata }\end{array}$ & $\begin{array}{c}\text { כשלון } \\
\text { failure } \\
\text { kiŠalon }\end{array}$ & $\begin{array}{c}\text { יר } \\
\text { moon } \\
\text { yare'ax }\end{array}$ \\
\hline $\begin{array}{c}2 \pi \\
\text { bring } \\
\text { hav }\end{array}$ & $\begin{array}{c}\text { enigma } \\
\text { raz }\end{array}$ & $\begin{array}{c}7{ }^{7} \\
\text { pure } \\
z a x\end{array}$ & $\begin{array}{c}\text { התנצחות } \\
\text { wrangling } \\
\text { hitnacxot }\end{array}$ & $\begin{array}{c}\text { מרקחה } \\
\text { turmoil } \\
\text { merkaxa }\end{array}$ & $\begin{array}{c}\text { קערה } \\
\text { bowl } \\
\text { ke'ara }\end{array}$ & $\begin{array}{l}\text { gת } \\
\text { give } \\
\text { ten }\end{array}$ & $\begin{array}{l}70 \\
\text { secret } \\
\text { sod }\end{array}$ & $\begin{array}{l}\text { חצ } \\
\text { pure } \\
\text { cax }\end{array}$ & $\begin{array}{c}\text { תחרות } \\
\text { competition } \\
\text { taxarot }\end{array}$ & $\begin{array}{c}\text { מהומה } \\
\text { disturbance } \\
\text { mehuma }\end{array}$ & $\begin{array}{l}\text { plate } \\
\text { claxat }\end{array}$ \\
\hline $\begin{array}{c}\text { פ } \\
\text { bull } \\
\text { par }\end{array}$ & $\begin{array}{c}\text { li } \\
\text { back } \\
\text { gev }\end{array}$ & $\begin{array}{l}\text { דיi } \\
\text { law } \\
\text { din }\end{array}$ & $\begin{array}{c}\text { רקיע } \\
\text { heavens } \\
\text { raki'a }\end{array}$ & $\begin{array}{c}\text { גער } \\
\text { reprimand } \\
\text { ge'ara }\end{array}$ & $\begin{array}{c}\text { תשורה } \\
\text { present } \\
\text { teŠura }\end{array}$ & $\begin{array}{l}\text { שור } \\
\text { ox } \\
\text { S̆or }\end{array}$ & $\begin{array}{c}\text { गג } \\
\text { body } \\
\text { guf }\end{array}$ & $\begin{array}{l}\text { תוק } \\
\text { law } \\
\text { xok }\end{array}$ & $\begin{array}{c}\text { שים } \\
\text { sky } \\
\text { Samaim }\end{array}$ & $\begin{array}{c}\text { ניפיפ } \\
\text { reprimand } \\
\text { nezifa }\end{array}$ & $\begin{array}{c}\text { מתני } \\
\text { gift } \\
\text { matana }\end{array}$ \\
\hline $\begin{array}{c}\text { ג } \\
\text { come } \\
g a \check{S}\end{array}$ & $\begin{array}{c}\text { ניוי } \\
\text { beauty } \\
\text { noi }\end{array}$ & $\begin{array}{l}\text { be } \\
\text { not } \\
\text { bal }\end{array}$ & $\begin{array}{c}\begin{array}{c}\text { o } \\
\text { meal } \\
\text { sesuda }\end{array} \\
\end{array}$ & $\begin{array}{c}\text { הוללות } \\
\text { debauchery } \\
\text { holelut }\end{array}$ & $\begin{array}{c}\text { נשואיi } \\
\text { marriage } \\
\text { nisu'in }\end{array}$ & $\begin{array}{c}\text { בוא } \\
\text { come } \\
\text { bo }\end{array}$ & $\begin{array}{c}\text { in } \\
\text { charm } \\
\text { xen }\end{array}$ & $\begin{array}{l}\text { kל } \\
\text { no } \\
\text { lo }\end{array}$ & $\begin{array}{l}\text { ארוחה } \\
\text { meal } \\
\text { aruxa } \\
\end{array}$ & $\begin{array}{c}\begin{array}{c}\text { שובעות } \\
\text { mischievousness } \\
\text { Šovavut }\end{array} \\
\end{array}$ & $\begin{array}{c}\begin{array}{c}\text { חתונה } \\
\text { wedding } \\
\text { xatuna }\end{array} \\
\end{array}$ \\
\hline$* 2$ & *135 & *34 & $* 2$ & *3 & $* 5$ & $* 31$ & *302 & $* 1314$ & *24 & *9 & *13 \\
\hline
\end{tabular}

*The stimulus lists with their average word frequency ratings according to Frost's website (per 1'000'000 words).

\section{References}

Almady, N. (2007). The contribution of vowel diacritics to reading comprehension in the voiced and silent reading of text by sixth grade reading disabled and regular Arab readers. Unpublished MA thesis, University of Haifa.

Baddeley, A. D. (1978). Working memory and reading. In P. Kolers, E. Wrolstad, \& H. Bouma (Eds.), Processing visual language ((pp, Vol. 1, pp. 355-370). New York: Plenum Press.

Baddeley, A. D., Thomson, N., \& Buchanan, M. (1975). Word length and the structure of short-term memory. Journal of Verbal Learning \& Verbal Behavior, 14, 575-589.

Bentin, S. (1997). Muda'ut fonemit ve rexishat kri'a (phonological awareness and reading acquisition). In J. Shimron (Ed.), Mexkarim be-psichologia shel halashon be-Israel (Psycholinguistic studies in Israel). Jerusalem: Magnes. in Hebrew.

Davis, C. (2005). Shallow vs non-shallow orthographies and learning to read workshop. Report of the OECD-CERI learning sciences and brain research. Cambridge University, UK: Co-hosted by The Centre for Neuroscience in Education.

Eshel, R. (1985). Effects of contextual richness on word recognition in pointed and unpointed Hebrew. Reading Psychology: An International Quarterly, 6, 127-143.

Even, D. (1995). Trumat hanikud lehavanat hanikra velemehirut hakri'a etsel talmidim mekitot bet vedalet halomdim beshitot hora'a shonot. The contribution of diacritical marks in Hebrew script to reading comprehension and reading speed among Grade 2 and Grade 4 pupils taught by two different instructional methods. Unpublished MA thesis, University of Haifa.

Frost, R. (1994). Prelexical and postlexical strategies in reading: Evidence from a deep and a shallow orthography. Journal of
Experimental Psychology. Learning, Memory, and Cognition, 20, $116-129$.

Frost, R. (1995). Phonological computation and missing vowels: Mapping lexical involvement in reading. Journal of Experimental Psychology. Learning, Memory, and Cognition, 21, 398-408.

Frost, R. (1998). Toward a strong phonological theory of visual word recognition: True issues and false trails. Psychological Bulletin, $123,71-99$.

Frost, R. (2006). Becoming literate in Hebrew: The grain-size hypothesis and semitic orthographic systems. Developmental Science, 9(5), 439-440.

Frost, R. (2009). Reading in Hebrew versus reading in English: Is there a qualitative difference? In K. Pugh \& P. McCardle (Eds.), How children learn to read: Current issues and new directions in the integration of cognition, neurobiology and genetics of reading and dyslexia research and practice (pp. 235-254). New York: Psychology Press.

Frost, R., Katz, L., \& Bentin, S. (1987). Strategies for visual word recognition and orthographical depth: A multilingual comparison. Journal of Experimental Psychology: Human Perception and Performance, 13, 104-115.

Jackson, N. E., \& Coltheart, M. (2001). Routes to reading success and failure. New York: Psychology Press.

Kahn-Horowitz, J. (1995). Developmental effects of reading without vowels. MA thesis. University of Haifa.

Koriat, A. (1984). Reading without vowels: Lexical access in Hebrew. In H. Bauma \& D. G. Bouwhuis (Eds.), Attention and performance X: Control of language processes (pp. 227-242). Hillsdale: Earlbaum.

Koriat, A. (1985a). Lateralization effects in reading pointed and unpointed Hebrew. British Journal of Psychology, 76, 161-173. 
Koriat, A. (1985b). Lexical access for low- and high-frequency words in Hebrew. Memory \& Cognition, 13, 37-44.

Liberman, A. M. (1989). Reading is hard just because listening is easy. In C. von Euler, I. Lundberg \& G. Lennerstrand (Eds.), Brain and reading: Wenner-Gren International Symposium Series, vol. 54 (pp. 197-205).

Miller, G. A. (1956). The magical number seven, plus or minus two: Some limits on our capacity for processing information. Psychological Review, 63, 81-97.

Miller, P. (2002). Communication mode and the processing of printed words: Evidence from readers with prelingually acquired deafness. Journal of Deaf Studies and Deaf Education, 7, 312-329.

Miller, P. (2004). The importance of vowel diacritics for reading in Hebrew: What can be learned from readers with prelingual deafness? Reading and Writing: An Interdisciplinary Journal, 17, 593-615.

Morhayim, H. (1988). Hashbaat derahim shonot benikud hatext al ketsev hakrija, jaholet hapianuah vehavanat hanikra shel talmidey kitot bet ve gimel. The impact of differences in the pointing of text on the reading rate, decoding ability and reading comprehension of second and third grade students. Unpublished MA thesis, University of Haifa.

Nachmani-Ronen, A. (2000). Trumat hanikud lehavanat hanikra bekerev kor'im mahilim besafa ha'ivrit. The contribution of diacritics to Hebrew reading comprehension among beginning readers. Unpublished MA thesis, University of Haifa.

Navon, D., \& Shimron, J. (1981). Does word naming involve grapheme-to-phoneme translation? Evidence from Hebrew. Journal of Verbal Learning and Verbal Behavior, 20, 97-109.

Navon, D., \& Shimron, J. (1985). Source and function of phonological code in processing written Hebrew. Final Report to the U.S. Israeli Binational Foundation, Haifa, Israel: University of Haifa, Institute of Information Processing and Decision Making.
Share, D. L. (1995). Phonological recoding and self-teaching: Sine qua non of reading acquisition. Cognition, 55, 151-218.

Share, D. L. (2008). On the Anglocentricities of current reading research and practice: The perils of overreliance on an "outlier" orthography. Psychological Bulletin, 134(4), 84-615.

Share, D. L., \& Levin, I. (1999). Learning to read and write in Hebrew. In M. Harris \& G. Hatano (Eds.), Learning to read and write: A cross-linguistic perspective (pp. 89-111). Cambridge: Cambridge University Press.

Shimron, J. (1993). The role of vowels in reading: A review of studies of English and Hebrew. Psychological Bulletin, 114, 52-67.

Shimron, J. (1997). Meharim bepsychologia shel halashon be'Israel: Rehishat lashon, keriah veketiva. Psycholinguistic research in Israel: Language acquisition, reading and writing. Jerusalem: Magnes Press.

Shimron, J. (1999). The role of vowel signs in Hebrew: Beyond word recognition. Reading and Writing: An Interdisciplinary Journal, $11,301-319$.

Shimron, J. (2006). Reading Hebrew: The language and the psychology of reading it. Mahwah: Lawrence Erlbaum Press.

Shimron, J., \& Sivan, T. (1994). Reading proficiency and orthography: Evidence from Hebrew and English. Language Learning, 44, 5-27.

Smolka, E., \& Eviatar, Z. (2006). Phonological and orthographic visual word recognition in the two cerebral hemispheres: Evidence from Hebrew. Cognitive Neuropsychology, 23(6), 972-989.

Ziegler, J., \& Goswami, U. C. (2005). Reading acquisition developmental dyslexia and skilled reading across languages: A psycholinguistic grain size theory. Psychological Bulletin, 13, 3-29.

Ziegler, J. C., \& Goswami, U. (2006). Becoming literate in different languages: Similar problems, different solutions. Developmental Science, 9(5), 429-436. 